\title{
The Effect of Federalization on the Defense Function
}

\author{
$B y$ DENNIS E. CURTIS
}

\begin{abstract}
The increasing federalization of crime gives rise to concurrent state and federal jurisdiction over most crimes. This dual jurisdiction enables prosecutors to choose whether to prosecute in state or federal courts. It is generally easier to obtain conviction in federal courts, and there is usually a large differential in the possible punishment under the different systems, with the federal system often having the harsher sentencing structure. As a result, prosecutors have enormous power to coerce guilty pleas or to choose the easiest path to conviction at trial. This concentration of power is worrisome, especially because there is at present no coherent policy about which crimes and which criminals should be prosecuted in state courts and which in federal courts. The result is that the prosecutorial advantages are employed randomly, with predictable results: wide disparities in sentences for similar offenses committed by like offenders, and marked differences in enforcement patterns across jurisdictions.
\end{abstract}

Dennis Curtis is Robert and Nanette Packard Professor and the director of clinical studies at the University of Southern California Law Center. Since 1970, he has supervised law students in clinical programs in which the students provide legal assistance to state and federal inmates. He is the author, with P. O'Donnell and M. Churgin, of Toward a Just and Effective Sentencing System (1977). Since 1990, he has been president of the Los Angeles City Ethics Commission. 
W HILE the increasing federalization of crime is becoming the subject of much debate, it is notfrom the criminal defense standpoint-a problem per se. The federal criminal justice system has its idiosyncrasies, but criminal defendants and defense lawyers must perforce operate within that system. Federal law has long proscribed a wide range of criminal activity, and congressional authority exists to reach most crimes. ${ }^{1}$

What is problematic for the defense is the dual jurisdiction that federalization enables. Currently, federal and state courts have concurrent jurisdiction over a wide variety of criminal behavior. Given the possibility of prosecution in either jurisdiction, increased federalization-more federal crimes-means more power to both state and federal prosecutors, who can cooperate to select defendants for pursuit and who can exploit the jurisdictional redundancy to their advantage. Moreover, the longstanding interpretation of the double jeopardy clause that permits sequential prosecutions in both state and federal court gives an added measure of power to prosecutors. ${ }^{2}$ Yet, even this dual jurisdiction could be justi-

1. Congress has comprehensive authority under the commerce clause to regulate and to proscribe various forms of criminal conduct. See Kathleen F. Brickey, "The Commerce Clause and Federalized Crime: A Tale of Two Thieves," this issue of The Annals of the American Academy of Political and Social Science; Sara Sun Beale, "Federalizing Crime: Assessing the Impact on the Federal Courts," ibid.

2. Under the dual sovereignty doctrine, "an act denounced as a crime by both national and state sovereignties is an offense against the peace and dignity of both and may be punished by each." United States v. Lanza, 260 U.S. 377, 382 (1922). Under the Department fied: were federal prosecutorial efforts carefully focused and indictment powers directed in specific and discrete areas, the repetitive authority might be rationalized to avoid duplicative efforts, create economies of scale, and perhaps cause a reduction in criminal activity. Alternatively, were federalization of particular crimes accompanied by disabling state prosecutions (that is, if Congress were to give the federal courts exclusive, rather than concurrent, jurisdiction over specific crimes), focused and nonduplicative deployment of resources could result.

Under the current system, however, neither deeply coordinated state-federal activities nor unitary focused action by either sovereign exists. Rather, erratic prosecution of and disparate penalties for similarly situated defendants are commonplace. This article focuses on how and why federalization does harm to defendants that, from a variety of vantage points, is cause for objection.

\section{THE SHAPE OF THE DUAL PROSECUTORIAL SYSTEM: OVERLAPPING, REDUNDANT, AND COOPERATIVE}

Questions of the effects on defendants of dual state and federal juris-

of Justice's Petite Policy, reprosecution after state prosecution for the same act is allowed only under compelling circumstances and with the approval of the assistant attorney general. See Katherine Lowe, "Twenty-Second Annual Review of Criminal Procedure: United States Supreme Court and Courts of Appeals 199192," Georgetown Law Journal, 81:1029, 1040 (1993); Petite v. United States, 361 U.S. 529, 530-31 (1960) (per curiam). But see H. Scott Wallace, "The Drive to Federalize Is a Road to Ruin," Criminal Justice, 8:52 (Fall 1993) (reprosecution sometimes occurs when state punishment seems too lenient). 
diction over criminal law must begin with the power of Congress to pass laws making activities federal offenses. It turns out that this power is almost unlimited, and the catalogue of federal crimes, long. ${ }^{3}$ Over the past decades, Congress has defined new federal offenses, promulgated increasingly harsh penalties for both new and old federal offenses, and provided additional resources for investigation and prosecution.

Congress has not endowed either the judiciary or the defense in a parallel fashion. The judicial dislike for these congressionally imposed burdens is well known and documented. ${ }^{4}$ Although commentators have deplored the congressional tendency to create new crimes ${ }^{5}$ and have attempted to articulate principles to limit or guide those decisions, ${ }^{6}$ no re-

3. See Brickey, "Commerce Clause and Federalized Crime."

4. See, for example, William $\mathrm{H}$. Rehnquist, 1993 Year-End Report on the State of the Judiciary, p. 2, reprinted in The Third Branch, 26:1, 1 (Jan. 1993) ("We can no longer afford the luxury of state and federal courts that work at cross-purposes or irrationally duplicate one another."); Roger J. Miner, "The Consequences of Federalizing Criminal Law: Overloaded Courts and a Dissatisfied Public," Criminal Justice, 4:16 (Spring 1989), p. 16.

5. Wallace, "Drive to Federalize."

6. Such principles have been argued for in Franklin E. Zimring and Gordon Hawkins, "Toward a Principled Basis for Federal Criminal Legislation," in this issue of The Annals of the American Academy of Political and Social Science; Philip B. Heymann and Mark H. Moore, "The Federal Role in Dealing with Violent Street Crime: Principles, Questions, and Cautions," ibid.; John B. Oakley, "The Myth of Cost-Free Jurisdictional Reallocation," ibid. See also Judicial Conference of the United States, Committee on Long Range Planning, Proposed Long Range Plan for the Federal Courts, Draft for Public Comment (Washing- alistic way of constraining the exercise of the congressional power exists.

The bulk of federal offenses has long overlapped state laws in defining various forms of behavior as criminal; as the number of federal crimes increases, so does the overlap. Drug and weapons offenses provide the most obvious examples, ${ }^{7}$ but a series of crimes more readily associated with the federal governmentsuch as money laundering, ${ }^{8}$ Hobbs Act violations (extortion principally), ${ }^{9}$ and offenses under the Racketeer Influenced and Corrupt Organizations Act (RICO) $)^{10}$-are also instances of dual jurisdiction, in which either federal or state prosecutors or both can prosecute individuals. Bank robberies and almost any fraud that involves the use of telephones or the mail also come simultaneously within the state and federal ambits.

While the federal courts are imagined by some to be a large system, the numbers of courts and judges are small as compared to their state counterparts. ${ }^{11}$ In light of the respective sizes of the federal and state

ton, DC: Judicial Conference of the United States, 1994), pp. 20-23; Sara Sun Beale, "Too Many and Yet Too Few: New Principles to Define the Proper Limits for Federal Criminal Jurisdiction," Hastings Law Journal, 46:979, 1004-18 (1995); Rory Little, "Myths and Principles of Federalization," ibid., 46:1029 (1995).

7. Most drug offenses are covered by 21 U.S.C. $\$ \S 841,960$. Weapons offenses are principally covered by 18 U.S.C. $\$ \S 922,924$. Use of a firearm in the commission of another crime comes under 18 U.S.C. $\$ \S 844,924,929$.

8. 18 U.S.C. $\S \S 1956,1957$.

9. 18 U.S.C. $\S 1951$.

10. 18 U.S.C. $\S \S 1962,1963$.

11. For a discussion of the impact of federalization on the federal courts in light of statistical data, see Beale, "Federalizing Crime." 
systems, it is a given that many, perhaps most, federal crimes can and will be prosecuted in state courts as state crimes. The great bulk of criminal prosecutions occur in state courts, not only because the number of cases is beyond the capacity of the federal judiciary (as currently configured and even if many times enlarged) but also because of the resources of federal prosecutors. Apart from crimes against the federal government (fairly characterized as truly federal crimes like treason and income tax violations), federal prosecutors can bring only a small percentage of criminal cases in any given area of criminal enforcement. In 1990, there were 829,344 felony convictions in the state courts, ${ }^{12}$ and 47,494 defendants convicted in the U.S. district courts. ${ }^{13}$ Thus, unless federal cases are carefully chosen, federal enforcement of crimes defined by Congress is likely to be scattershot and have relatively little effect upon the underlying criminal behavior. Even in drug cases, in which the federal effort has been highly visibleand costly-federal convictions are about 6 percent of state and federal drug convictions combined. ${ }^{14}$

The limited number of federal criminal prosecutions, then, can have real impact only if there is a national

12. U.S., Department of Justice, Office of Justice Programs, Bureau of Justice Statistics, Sourcebook of Criminal Justice Statistics 1993, ed. Kathleen Maguire and Ann L. Pastore (Washington, DC: Government Printing Office, 1994), p. 490.

13. Ibid., p. 535.

14. For the year 1990 , an estimated 274,613 adults were convicted on felony drug charges in state courts. Federal convictions for drug crimes during 1990 numbered 16,311. Ibid., pp. $490,535$. policy that sets forth the kinds of cases and the kinds of criminals that should be the targets of the federal effort, and is accompanied by equally strong directives not to bring cases where the criteria are not met. But such national coordination is undercut by the structure of federal prosecution, which is diffused. In practice, individual United States Attorneys differ widely both in the selection of offenders to prosecute and in the choice of which crimes to charge. While decentralization of federal prosecutions may have a good deal to commend it in a variety of contexts, such localized power does not offer a basis upon which to deploy federal prosecutors according to carefully calibrated national directives. While written Department of Justice guidelines exist, no national policy sufficiently curbs individual prosecutorial choices. The result is that there is federal prosecution of many crimes and of many criminals, indistinguishable from crimes and criminals routinely prosecuted by state agencies.

But to say that federal enforcement practices vary widely and, in large part, end up being duplicative of state enforcement does not necessarily mean that state and federal law enforcement agencies pursue totally independent courses. On the contrary, there is already in place a close relationship between many federal and state law enforcement personnel, particularly in drug cases. Assistant United States Attorneys, state district attorneys, state and local police and other law enforcement personnel, as well as agents of the Drug Enforcement Administration, the Bureau of Alcohol, Tobacco and 
Firearms, and the Federal Bureau of Investigation, are all routinely crossdesignated to investigate and prosecute crimes in both state and federal courts. Joint state-federal task forces abound. State law enforcement officials are encouraged to make referrals for federal prosecution of crimes within state jurisdiction.

One would think that this increased cooperation by state and federal law enforcement personnel could provide an atmosphere in which a coherent policy could develop about when to prosecute in state courts and when to prosecute in federal courts. No such overall policy has emerged, however. All prosecutors have pressures, including political needs to be reactive to criminal activity. Prosecutors need to be responsive to cooperating agencies who have done investigative work and who want to see and report the fruits of such efforts. While a degree of cooperation and coordination may exist in a particular jurisdiction, the overall interrelations have not yielded a holistic approach that sorts cases by jurisdiction, state and federal, or an approach that enables nuanced responsiveness to local needs.

\section{EFFECTS ON DEFENDANTS: PROSECUTORIAL ADVANTAGES}

Several factors-the probability of federal prosecution, the probability of double prosecution for the same offense, the relative probabilities (state and federal) of conviction, and the effect of differing state and federal sentencing practices-affect defendants, about whom one cannot speak without also discussing prosecutors.
At one level, given the data on the relative capacities of state and federal prosecutions, the probability of prosecution in federal court, at least for most people accused of crimes, is always relatively low. The probability of double prosecution is also quite low-although there are several notable exceptions. ${ }^{15}$

Overall instances of federal prosecutions, however, tell only one part of the story. Criminal defendants and their lawyers often are faced with the potential for dual prosecutions or federal prosecution. They must always "[bargain] in the shadow of the law."16 Moreover, once threatened with actual federal prosecution, defendants face prosecutors who possess awesome power. Conviction either by trial or through plea bargaining becomes more certain, and sentence exposure is generally higher in federal court than if a defendant were subject only to state prosecution.

\section{Probability of prosecution}

As noted, in 1990 there were 274,613 state felony drug offense convictions; in federal courts, 16,311 defendants were convicted of drug offenses. ${ }^{17}$ For violent offenses-

15. The police officers who battered Rodney King, for example, were tried and convicted in federal court after state prosecutors failed to obtain a conviction.

16. The quotation is taken from the title of Robert H. Mnookin and Lewis Kornhauser's article, "Bargaining in the Shadow of the Law: The Case of Divorce," Yale Law Journal, 88:950 (1979).

17. Department of Justice, Sourcebook of Criminal Justice Statistics 1993, pp. 490, 535. Approximately 61 percent of the state drug convictions were for trafficking offenses, and the remainder for possession charges. Approxi- 
murder, assault, robbery, and the like-there were 147,766 convictions in the state courts and 2331 federal convictions. ${ }^{18}$ In the case of property offenses-burglary, larceny, fraudthe conviction numbers were 280,748 for state cases compared to 13,593 for federal cases. ${ }^{19}$

These kinds of ratios give the impression that federal prosecutions are relatively rare events, but several factors can increase the probability of federal prosecution of a particular individual. First, federal enforcement authorities generally have more resources to spend per case than their state counterparts. Thus, in the instances where state and federal authorities are cooperating, federal resources are often employed where the target is large-scale criminal activity by an organized group. Federal prosecutions of organized crime kingpins, large-scale drug dealers, and white-collar criminals who engage in multimillion-dollar fraud schemes are cases in point, and there are, in fact, plenty of these. ${ }^{20}$ Organized crime cases are especially likely to end up in federal court, primarily because of the relative ease of conviction in federal court, as compared with many state courts, as will be described more fully in this article.

Yet far from all federal prosecutions target big-time offenders. Drug

mately 92 percent of the federal convictions were for trafficking offenses. Ibid., pp. 490, 535.

18. Ibid.

19. Ibid.

20. In 1990 , there were 996 defendants charged with federal racketeering offenses and 128 charged with continuing criminal enterprise drug offenses. Ibid., pp. 514-15. offenses provide an example. Drug offenders make up a large part of the recent dramatic increase in the federal prison population. In 1980, about 18 percent of the 24,000 federal prisoners were drug law offenders. In 1993 , about 60 percent of the nearly 77,000 sentenced inmates were confined for drug law violations. Of these, many did not meet the description of the so-called drug lord. A Department of Justice study found that some 36 percent of all sentenced drug offenders in the federal prison system could be classified as "low-level drug law offenders." 21

Why should so many low-level drug offenders find their way to federal prisons? Why are these low-level offenders not turned over to the states for prosecution, especially given the close cooperation between federal and state authorities in drug cases? One reason is that low-level drug dealers are relatively easy to catch and prosecute, and federal agencies are understandably eager to demonstrate proof of their success in apprehending criminals. Because the lowlevel drug offenders operate mostly at street level, "buys" by undercover agents and reverse stings ${ }^{22}$ are relatively easy to arrange. Street-level people end up in federal prisons in large numbers because they generally know less about the distribution organization of which they are a part-and thus have less to trade in

21. Criminal Law Reporter (Bureau of National Affairs) 54:2101, 2109 (16 Feb. 1994).

22. A reverse sting occurs when a suspected drug dealer is persuaded to buy drugs from an undercover agent or from an informer who is equipped with an electronic voice transmitter, or wire. 
return for lenient treatment ${ }^{23}$-than do higher-ups in the drug ring. The combination of very high possible sentences for relatively low quantities of drugs sold or possessed, and wide discretion on the part of federal prosecutors to charge crimes with penalties that span across a wide range, means that guilty pleas can be obtained in a large number of these cases, resulting in an increase in the conviction ratios, which is used as a measure of success by and for federal prosecutors and investigatory agencies.

While federal prosecutions may be rare, once the federal lightning strikes, the sentence is likely to be much higher than if the defendant had been convicted in many state courts. Though the ranges of punishment can vary widely between state and federal systems, and although many state legislatures are increasing penalties and imposing threestrike provisions, currently the federal system has more severe sanctions for certain crimes than do many states. ${ }^{24}$ This disparity translates into more time in prison for

23. Under U.S. Sentencing Guideline (U.S.S.G.) $\S 5 \mathrm{~K} 1.1$, if a defendant provides the government "substantial assistance in the investigation or prosecution of another person who has committed an offense," the court can impose a sentence less severe than recommended by the guidelines, upon the government's motion. One of the criteria for determining the appropriate sentence reduction is "the court's evaluation of the significance and usefulness of the defendant's assistance, taking into consideration the government's evaluation of the assistance rendered." U.S.S.G. $§$ $5 \mathrm{~K} 1.1(\mathrm{a})(1)$.

24. For additional discussion of federal sentencing policy, see Kevin R. Reitz, "The Federal Role in Sentencing Law and Policy," this issue of The Annals of the American Academy of Political and Social Science. defendants who have been prosecuted federally than for state defendants who commit similar offenses. ${ }^{25}$ It also means that state defendants, when threatened with federal prosecution, have the added incentive of removing the threat of federal prosecution if they agree to plead guilty to state charges.

\section{Ease of conviction}

If a defendant is either the subject of a joint state-federal investigation or indicted in the federal system, that defendant's conviction becomes more probable. There are three primary reasons for this. First, procedural rules in the federal courts make convictions easier for federal prosecutors than for their state counterparts. Second, prosecutors in the federal system have substantial coercive power to compel guilty pleas. ${ }^{26}$ Third,

25. In 1990, the average length of prison sentences imposed on persons convicted of drug trafficking offenses in the federal courts was 83.1 months, while in state courts, drugtrafficking offenders received average sentences of 52.0 months. Department of Justice, Sourcebook of Criminal Justice Statistics 1993, pp. 495, 537. The case of Adewale Aladekoba demonstrates that prosecutors might prefer federal prosecutions for drug offenses rather than state murder charges. In that case, state murder charges were dropped, and during the federal drug trial the prosecution was able to demonstrate involvement in three murders as part of Aladekoba's drug activities. Aladekoba was sentenced to multiple life terms without the possibility of parole, more than he would have received from a state prosecution. See Jay Apperson and Marcia Myers, "Prosecutors Increasingly Rely on Federal Charges," Baltimore Sun, 9 Apr. 1994; Beale, "Too Many and Yet Too Few," pp. 1000-1001.

26. Some state prosecutors do as well, of course, with the advent of three-strike laws. 
when both federal and state prosecutors are involved in a criminal investigation, the panoply of inducements and threats that can be brought to bear to extract guilty pleas increases substantially.

Procedural advantages. Federal prosecutors enjoy several procedural advantages over most of their state counterparts. ${ }^{27}$ One set of issues relates to grand juries. In many state jurisdictions, including New York and California, prosecutors cannot present hearsay evidence to grand juries except in narrowly defined areas. Thus accomplices, eyewitnesses, and victims must appear personally before many state grand juries, rather than having an investigating agent summarize the testimony of these witnesses for the grand jury, as is done in the federal system. Consequently, state prosecutors need to spend time and resources preparing often unwilling witnesses who must appear before a grand jury-not so for federal prosecutors, who need only prepare the Federal Bureau of Investigation or Drug Enforcement Administration case agent. Witnesses in the federal system may also feel more secure because they may well escape identification as witnesses when their testimony is related, not by them, but by a government agent, sworn to secrecy for grand jury testimony.

In some states, defendants have a right to a preliminary hearing whenever a charge is brought against them. Defense attorneys are given

27. I am indebted to the article by John C. Jeffries, Jr. and John Gleeson, “The Federalization of Organized Crime: Advantages of Federal Prosecution," Hastings Law Journal, 46: 1029 (1995), for most of the following examples. the opportunity to cross-examine witnesses, including reporting officers, and they use this opportunity to obtain discovery about the strength of the prosecution's case and to lock witnesses into accounts that cannot easily be changed later at trial. In contrast, in the federal system, prosecutors routinely short-circuit the preliminary hearing by obtaining indictments through a grand jury, ${ }^{28}$ depriving the defense of these opportunities.

Another federal advantage is that prosecutors can compel testimony by the grant of limited, or use, immunity, meaning that the government can still prosecute an immunized witness if it can demonstrate that the evidence for that prosecution "was obtained from a source independent from the immunized testimony. ${ }^{\text {29 }} \mathrm{On}$ the other hand, many states, again including New York and California, allow only the use of transactional immunity, meaning that the immunized witness is protected from prosecution for any activity he or she testified about in the immunized testimony. State prosecutors often will not risk giving transactional immunity to a witness when that witness might be involved more deeply in the offense being investigated than initially appears or when the immunized witness may be involved in another offense that might be

28. The Federal Rules of Criminal Procedure provide for preliminary hearings, but these hearings are not available to defendants if the prosecutor decides to obtain an indictment through the grand jury.

29. Charles H. Whitebread, An Analysis of Constitutional Cases and Concepts (Mineola, NY: Foundation Press, 1980), p. 262. 
inadvertently touched upon in a grand jury investigation.

Turning to trials, state rules generally do not allow convictions based on accomplice testimony alone but require independent corroborative evidence linking the defendant to the crime.$^{30}$ Moreover, the corroboration requirement often cannot be avoided by the interlocking testimony of several accomplices. ${ }^{31}$ In contrast, federal rules allow conviction on the uncorroborated testimony of an accomplice. ${ }^{32}$ Given that higher-ups in sophisticated criminal enterprises often operate behind the scenes and limit their contacts with lower echelons, co-conspirator testimony may be the only way to make a case, leaving state prosecutors limited opportunities for getting convictions against the most culpable offenders in at least some cases of this type.

$\mathrm{RICO}^{33}$ is yet another coercive weapon in the federal arsenal. When the threat of RICO is combined with the absence of a requirement of corroboration, federal prosecutors have a powerful lever for obtaining convictions. Convictions under RICO require proof merely that a defendant is a member of an organization that engaged in a pattern of racketeering activity, and such a pattern can be proved by as few as two predicate acts. Given that uncorroborated accomplice testimony about a defendant's participation in one or another of the predicate acts can be sufficient

30. Jeffries and Gleeson, "Advantages," pp. 15-20.

31. Ibid.

32. Caminetti v. United States, 242 U.S. 470, 495 (1917); United States v. Gordon, 987 F.2d 902, 906 (2d Cir. 1993).

33. 19 U.S.C. $\S \S 1961$ et seq. for conviction, RICO indictments put tremendous pressure on defendants.

Plea bargaining. In addition to relative ease of conviction, the adoption within the federal system of a guideline sentencing scheme, together with the proliferation of mandatory minimum sentences, has given prosecutors enormous power in plea negotiations. ${ }^{34}$ Broadly speaking, federal prosecutors have more control over sentencing than ever before. Judges no longer have the discretion to select and impose a sentence within wide boundaries of statutory maxima and minima. Rather, sentencing is now carried out in accordance with guidelines promulgated by the United States Sentencing Commission.

Because judges have limited authority to depart from these congressionally mandated Sentencing Guideline ranges, federal prosecutors can manipulate the guidelines upward or downward by deciding what crimes to charge, by controlling the information that is furnished to sentencing judges, by promising rewards for cooperation, or by threatening to indict on every conceivable charge. The charging decision, of course, directly affects the calculation of the offense category. For example, a typical range for a drug offender with one prior felony conviction who had imported four kilos of cocaine might be 108-35 months. ${ }^{35}$ But a prosecutor

34. See Dennis E. Curtis, "Mistretta and Metaphor," Southern California Law Review, 66:607, 608-11 (1992); "Symposium on Federal Sentencing," Southern California Law Review, 66:99 (1992).

35. U.S.S.G. § 2D1.1 (amount of cocaine imported) and § 4A1.1 (criminal history). 
might, in a drug indictment, put in or leave out an allegation that a sale or a buy took place within 1000 feet of a school, thus exposing the defendant to a guideline range of $135-68$ months, or the possibility of about three years of added incarceration.

Federal sentences are often dependent upon the amount of the illegal substance involved in a drug conviction or the amount of money involved in a fraud offense. Information on the amount of drugs or money involved in a series of illegal deals, for example, might be purposefully underestimated by the prosecutor in documents presented to the judge, yielding a lower offense category under the guidelines. On the other hand, by presenting testimony of a myriad of drug deals, the prosecutor can maximize the amount of drugs involved, greatly increasing the guideline range.

Mandatory minimum sentences for certain crimes ${ }^{36}$ strengthen the federal prosecutor's hand even further. For example, prosecutors who

36. The vast majority of mandatory minimum sentences are imposed under four statutes dealing with drugs and possession of firearms in certain crimes: 21 U.S.C. $\$ \S 841,844$, 960, and 924(c). See Kathleen F. Brickey, "Criminal Mischief: The Federalization of American Criminal Law," Hastings Law Journal, 46:1135, 1148-50 (1995). Mandatory minimums have in fact affected all federal sentences, however, through their incorporation into the Sentencing Guidelines. Guideline sentence levels were set so that sentences imposed under the guidelines would be longer than those required by the mandatory minimums for all but the least culpable offenders. The mandatory minimum sentences are thus really a floor for sentencing under the guidelines. Barbara S. Vincent and Paul J. Hofer, The Consequences of Mandatory Minimum Prison Terms: A Summary of Recent Findings (Washington, DC: Federal Judicial Center, 1994), p. 3. decide not to charge a gun count-the use of a gun in the commission of a drug offense, for instance-can allow defendants to escape a mandatory minimum five-year sentence consecutive to whatever is imposed in connection with the underlying offense. Conversely, the prosecutor's decision to include a count that carries a mandatory minimum sentence of ten years, twenty years, or life puts tremendous pressure upon the most stouthearted of defendants, whether innocent or guilty. Also, in the guideline scheme, rewards for cooperation are almost completely controlled by the prosecutor. With few exceptions, judges cannot reward cooperation with a reduced sentence without a motion by the prosecutor requesting such a reward..$^{37}$

In the event that a prospective criminal defendant becomes the subject of a joint federal-state investigation, even stronger pressures can be brought to bear. There will always be a differential between state and federal laws as to the sentencing exposure. In most cases, the prospective federal sentence will be harsher. Also, state sentencing systems are currently more flexible than the federal system and are likely to remain so, allowing probation, for example, when probation is not available in the federal system. Finally, as noted ear-

37. 18 U.S.C. § 3553(e), entitled “Limited authority to impose a sentence below a statutory minimum," provides for such authority only upon motion of the government. A recent amendment contained in the 1994 Crime Bill allows judges to impose less than the mandatory minimum term for nonviolent drug crimes by offenders with minor criminal histories. Pub. L. No. 103-322 80001, 108 Stat. 1796, 1985 (1994). 
lier, conviction at trial in most cases will be more probable in federal court.

Because of dual jurisdiction, state prosecutors are the beneficiaries of all of the federal prosecutorial advantages, including the harsher federal sentencing system. In this way, they share either directly or indirectly the power of federal prosecutors. The very existence of dual systems casts a shadowy threat of federal prosecution in almost every case, even though the number of federal prosecutions is actually small compared with state prosecutions. In the instance when the two sovereigns do collaborate, great pressure can be applied. A defendant confronted by a state-federal joint task force has a difficult decision to make: for example, should the defendant plead guilty in state court and have a guaranteed three-year sentence, or should the defendant go to trial in federal court under an indictment that would entail a sentence of thirty years?

\section{THE HARMS THAT FLOW}

That defendants have hard choices is not intrinsically bad. If one viewed defendants as likely to be culpable, the system that has been sketched here could well be applauded. Should one worry about the power of prosecutors to coerce guilty pleas or be concerned with the sentencing disparity that results from dual criminal jurisdiction? When someone commits a crime, does that offender have a right to be prosecuted in the more lenient jurisdiction, or do criminals simply have to take their chances?

The answers, I think, come not only from the defense perspective but from everybody's point of view. A fair criminal justice system should distinguish between degrees of culpability. There is an interest in punishing the worst actors more harshly and, conversely, in providing opportunities for the innocent to have an effective way to protest indictments and to defend themselves. There is also an interest in not concentrating too great a set of powers in government and in creating incentives for thoughtful and efficient government action against individuals who have committed criminal offenses. At a minimum, then, at least some of the purposes of the criminal justice system should be to avoid convicting the innocent, to convict the guilty only of what can be proven that they did, to sentence the convicted offender in proportion both to the seriousness of the crime and the offender's culpability in the crime, and to expend public resources wisely.

Thus the complaints about the current duplicative, overlapping, and cooperative system are that, at the margins, more defendants will be convicted of crimes that they did not commiteven though they may have committed some lesser or different crimes-and more innocent people will be convicted and punished. Moreover, for those convicted, sentence disparity will be the rule rather than the exception. Those defendants selected to receive federal convictions and long federal sentences are the unfortunates who, almost by happenstance, come within the federal system.

That the criminal justice system is not always fair is not news. But the sort of conviction and sentencing disparity that occurs as the result of 
dual criminal jurisdiction is objectionable on grounds not often discussed: the criminal justice system should be fair not only as an abstract matter but because the justice system has the obligation to teach responsibility and evenhandedness. When participants in the systemdefendants, attorneys, witnesses, law enforcement agents-perceive that the system is erratic and unfair, harm is done to those participants as well as to the public at large. When a less culpable offender receives a sentence much harsher than his or her superior in a criminal conspiracy, or a conviction on a count in which he or she was not involved, that person's sense of basic justice and respecthow to treat other people-must be affected, even if only minimally or at the margins. ${ }^{38}$

A second argument against the grant of so much power to prosecutors as is enjoyed currently by federal-and, derivatively, state-prosecutors is that defendants should be able to plea-bargain with a realistic chance of a discount depending upon the strength of the prosecution's case. Dual jurisdiction defeats that goal. One might respond that defendants

38. In what is becoming a well-cited example, a drug defendant in Philadelphia was offered a plea bargain by local prosecutors requiring a 4-8 year sentence. When the defendant turned down the offer, the local and federal prosecutors decided to bring the charges in federal court, where because of two prior convictions, the defendant received a mandatory life sentence. At sentencing, the judge stated, "Yeah, there are people who are worse than you out on the street. But you're here, and you're going to jail. And the law says you have to go to jail for the rest of your life." Jim Smith, "Petty Pusher Goes Out Big Time," Philadelphia Daily News, 17 July 1992. should be charged with what the prosecutor believes that they did, and should not receive discounts depending upon whether or not they are perceived as difficult to convict. Accepting the merit in that argument does not, however, end discussion. The difficulty of conviction reflects at least in some sense a doubt of actual guilt, that is, "if we can't prove it, maybe they didn't do it, or didn't do all of it, or didn't have too much to do with it." Moreover, both state and federal judiciaries are deeply dependent on plea bargaining; removing all incentives for compromise takes the bargaining out of pleading guilty.

Does the current system go so far as to obviate prosecutors' need to bargain? Will prosecutors not always give better deals to defendants about whom convictions seem less sure? The answer is yes, but with a substantial caveat. As the balance tips further, as procedural and substantive law protections for defendants become increasingly illusory, the correlation between deals offered to defendants and the probability of conviction at trial are reduced.

\section{CONCLUSION}

Dual jurisdiction-overlapping, redundant, and cooperative-in a context of severe and disparate sentencing possibilities, together with wide prosecutorial discretion and the pressures of production, push participants away from balanced, considered judgment. The prospect of such unbridled governmental power, even when exercised by people with the best of motives, should cause all of us deep concern. 